\title{
КЛІНІЧНА ЕФЕКТИВНІСТЬ ВИКОРИСТАННЯ КОМБНОВАНОГО АМІНОКИСЛОТНОГО КОМПЛЕКСУ В ЛІКУВАННІ ХВОРИХ НА ДІАБЕТИЧНУ ПЕРИФЕРІЙНУ ПОЛІНЕЙРОПАТІЮ
}

\begin{abstract}
Резюме. Стандартне лікування діабетичної полінейропатії, одного із найбільш частих і поширених ускладнень цукрового діабету, є ефрективним, але приводить лише до тимчасового клінічного ефекту.

Мета дослідження - підвищити ефективність лікування невропатичного болю шляхом включення препарату “Келтікан" у комплексну терапію діабетичної полінейропатії.

Матеріали і методи. Наявність невропатичного болю діагностували за допомогою модисрікованого опитувальника DN4 (2005).

Результати досліджень та їх обговорення. Обстежено 64 хворих на цукровий діабет (ЦД) 2 типу, ускладнений діабетичною полінейропатією. Пацієнтів поділили на дві групи: до контрольної групи увійшло 32 хворих, які отримували стандартне лікування, 32 пацієнтів дослідної групи додатково отримували препарат "Келтікан" по 1 капсулі тричі на добу впродовж місяця. Оцінку та інтенсивність невропатичного болю проводили за допомогою модифрікованого опитувальника DN4. Bстановлено позитивний клінічний ефект лікування в обох групах після 12-ти денного лікування, який зберігався впродовж місяця в обох групах, а через 3 і 6 місяців лише у групі з додатковим призначенням келтікану.

Висновки. Використання опитувальника DN4 з модифікованою шкалою оцінки показників невропатичного болю дозволяє оптимізувати діагностику даного ускладнення у хворих на цукровий діабет. Включення препарату “Келтікан" у стандартну комплексну терапію діабетичної полінейропатії підвищує клінічну ефективність лікування невропатичного болю та сприяє збереженню лікувального есректу протягом 6 місяців у 64,2 \% хворих.
\end{abstract}

Ключові слова: діабетична полінейропатія; невропатичний біль; препарат “Келтікан”.

ВСтУП Соціально-економічна значимість цукрового діабету (ЦД) зумовлена не лише його поширеністю, але й значними матеріальними витратами, пов'язаними з тимчасовою або постійною непрацездатністю пацієнтів унаслідок розвитку ускладнень даного захворювання, зокрема діабетичної периореричної полінейропатії (ДПН) [3]. За даними літератури [7], частота їі виявлення у стаціонарних хворих складає 30-40 \%, в амбулаторних пацієнтів це ускладнення зустрічається у понад 70 \% випадків.

Необхідно зазначити, що у половини хворих дПн перебігає без суб'єктивних ознак і виявляється лише при ретельному об'єктивному та неврологічному обстеженні. Разом з тим, у 10-20 \% пацієнтів при впершевиявленому ЦД 2 типу вже має місце виражений периферичний больовий синдром, який є віддзеркаленням ураження дрібних нервових волокон. Зазначимо також, що різко ДПН і, зокрема невропатичний біль, знижує якість життя хворих і вимагає довготривалого лікування [12].

Сучасна патогенетична терапія ДПН включає призначення препаратів альфа-ліпоєвої кислоти, актовегіну, вітамінів групи В [1-7]. Проте клінічного ефректу не завжди вдається досягти, що потребує пошуку нових методів лікування невропатичного болю при діабетичній полінейропатії. На сьогодні в арсеналі лікарів $€$ небагато препаратів, які б діяли на рівні периферичних нервів і сприяли б їх фрізіологічній регенерації. Тому застосування препарату "Келтікан”, до складу якого входять активні складові ряду амінокислот - цитидину-5'-динатрію моносроссрату; уридину-5'-тринатрію триоросфрату, уридину-5'-динатрію дифоссрату, уридину-5'-динатрію моносоосфату, що мають регенароторні, трофрічні та знеболювальні ефректи, [13, 14], у комбінованій терапії ДПН може покращити ефективність лікування даного неврологічного ускладнення ЦД.

Метою дослідження було підвищити ефективність лікування невропатичного болю шляхом включення препарату “Келтікан” у комплексну терапію діабетичної полінейропатії.

МАТЕРІАЛИ І МЕТОДИ Обстежено 64 Хворих на ЦД 2 типу, ускладнений діабетичною полінейропатією. Вік обстежених становив від 45 до 65 років (середній вік
$(57,09 \pm 6,18)$ року). Тривалість ЦД склала від 5 до 19 років (середня тривалість $(9,34 \pm 3,61)$ року), а ДПН $-1-12$ років (середня тривалість $(5,05 \pm 2,85)$ року). Серед обстежених було 33 (51,56 \%) чоловіків і 31 (48,44 \%) жінка. Всіх обстежених поділили на дві групи: до контрольної групи (перша група) увійшли 32 пацієнтів, які отримували стандартне лікування згідно з уніфрікованим клінічним протоколом первинної та вторинної (спеціалізованої) медичної допомоги (№ 1118 від 21.12.2012) [8]. 32 хворих дослідної групи (друга групи) додатково отримували препарат “Келтікан" по 1 капсулі тричі на добу впродовж місяця. Групи зіставили за віком, тривалістю ЦД та діабетичної полінейропатії. Клінічне обстеження пацієнтів здійснювали до початку лікування та на 12 день після початку лікування.

Наявність невропатичного болю діагностували за допомогою модисрікованого опитувальника DN4 (2005) [911], що складається з двох блоків запитань: перший блок - 7 запитань до хворого для виявлення сенсорних симптомів, таких, як спонтанний біль (відчуття печії, болюче відчуття холоду, відчуття, як від ударів током), парестезії та дизестезії (відчуття повзання мурашок, поколювання, оніміння, свербіж); другий блок - 3 висновки лікаря на основі клінічного огляду, що дає можливість лікарю виявити алодинію та негативні сенсорні симптоми. Сума балів понад 4 свідчить про наявність у пацієнта невропатичного болю. Ми запропонували модисрікацію першого блоку даного опитувальника за рахунок уточнення кожного запитання за шкалою від 1 до 10, що дозволяє оцінити не лише позитивні сенсорні відчуття, але і їх інтенсивність.

Результати оцінювали при госпіталізації та через 12 днів після початку терапії діабетичної полінейропатії. Через 3 і 6 місяців проводили телефонне опитування пацієнтів з першого блоку запитань опитувальника.

Аналіз й обробку статистичних даних результатів клінічних обстежень проводили на персональному комп'ютері з використанням пакета прикладних програм STATISTICA 10 та MS Excel XP. Порівняння абсолютних величин здійснювали за допомогою $\chi^{2}$ - критерію Пірсона (хі-квадрат). Порівняння показників у групі проводили за 
допомогою непараметричного методу Вілкоксона, а між групами - Стьюдента. Різницю показників вважали вірогідною при показнику р<0,05.

РЕЗУЛЬТАТИ ДОСЛІДЖЕНЬ ТА ЇХ ОБГОВОРЕННЯ Згідно з опитувальником DN4, до лікування невропатичний біль турбував 50 (78,13 \%) обстежених, що відповідає даним літератури [1, 2]. Значимих відмінностей між групами до лікування не було ( $>>0,05),($ табл. 1).

Розподіл суб'єктивних ознак у дослідній групі пацієнтів показав, що відчуття печіння турбувало 65,63 \% хворих, холоду - 34,38 \%. Повзання мурашок відчували 70,31 $\%$ осіб. Відчуття як від удару струму було у 42,19 \% пацієнтів із діабетом. Поколювання та оніміння мало місце у понад 60 \% хворих. Скарги на свербіж були у 32,81\% опитаних. При обстеженні хворих біль локалізувався у ділянці зі зниженою чутливістю до доторкування (у 75 \%), до поколювання (в 45,31 \%) і в ділянці подразнення пензликом (у 23,44 \%) досліджуваних.

Проведене лікування сприяло зменшенню показників невропатичного болю, сприяло позитивній динаміці інтенсивності суб'єктивних скарг пацієнтів. Аналіз даних опитувальника DN4 показав зменшення ознак невропатичного болю на $9,4 \%\left(x^{2}=2,494 ; p>0,05\right)$ у хворих контрольної групи та на 28,1 \% $\left(X^{2}=27,589 ;\right.$ p<0,05) в групі осіб, які додатково отримували лікування келтіканом.
Показник наявності невропатичного болю після курсу лікування був вірогідно меншим у другій групі.

Динаміка окремих показників невропатичного болю у кожній із груп на 12-й день після початку лікування виявила, що у пацієнтів першої групи відчуття печіння зменшилося на $15,63 \%\left(\chi^{2}=1,602 ; p>0,05\right)$, в осіб другої групи - на 31,25 \% $\left(X^{2}=6,250 ; p<0,05\right)$. Відчуття холоду знизилось не вірогідно в обох групах на $6,25 \%\left(X^{2}=0,277 ; p>0,05\right)$ та $12,5 \%\left(X^{2}=1,333\right.$; $\mathrm{p}>0,05)$ відповідно. Відчуття удару струму стало меншим на $28,13 \%\left(X^{2}=6,488 ; p<0,05\right)$ пацієнтів першої групи та на 31,25 $\%\left(X^{2}=7,265 ; p<0,01\right)$ в осіб другої групи, повзання мурашок турбувало менше на $12,5 \%\left(X^{2}=1,016 ; p>0,05\right)$ та 28,125 \% $\left(x^{2}=5,497 ; p<0,05\right)$ хворих на діабет першої і другої груп відповідно. Поколювання та оніміння зменшилося на 21,88 \% $\left(X^{2}=3,090 ; p<0,05\right)$ та $3,125 \%\left(X^{2}=3,090 ; p>0,05\right)$ пацієнтів першої групи та 34,38 \% ( $\left.\chi^{2}=7,630 ; p<0,01\right)$ i 15,63\% $\left(\chi^{2}=7,630\right.$; $\mathrm{p}<0,05)$ осіб другої групи. Свербіж став турбувати менше на $3,125 \%\left(X^{2}=0,080 ; p>0,05\right)$ опитаних першої групи і 15,63 \% $\left(X^{2}=2,003 ; p>0,05\right)$ другої групи. Біль, що локалізувався в ділянці зменшеної чутливість до доторкування, зменшився на $15,63 \%\left(x^{2}=1,871 ; p>0,05\right)$ та $25 \%\left(x^{2}=4,146 ; p<0,05\right)$, до поколювання - на $25 \%\left(\chi^{2}=4,433 ; p<0,05\right)$ та $31,25 \%$ $\left(X^{2}=4,654 ; p<0,05\right)$, подразнення пензликом - на $6,25 \%$ $\left(X^{2}=0,333 ; p>0,05\right)$ і 15,63 \% $\left(X^{2}=4,010 ; p<0,05\right)$ в обстежених першої і другої груп відповідно (табл. 2).

Таблиця 1. Динаміка вираження невропатичного болю в обстежених групах хворих на цукровий діабет за даними

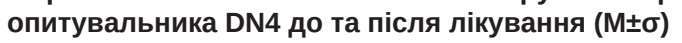

\begin{tabular}{|l|c|c|c|}
\hline \multicolumn{1}{|c|}{ Група } & Перша група & Друга група & $\mathrm{p}$ \\
\hline До лікування & $4,656 \pm 1,405$ & $5,031 \pm 1,421$ & $\mathrm{p}>0,05$ \\
\hline Після лікування & $3,375 \pm 1,476$ & $2,188 \pm 1,061^{*}$ & $\mathrm{p}<0,05$ \\
\hline
\end{tabular}

Примітка. * - різниця до і після лікування достовірна $(\mathrm{p}<0,05)$.

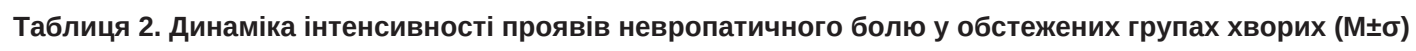

\begin{tabular}{|c|c|c|c|c|c|c|c|c|c|}
\hline \multirow{3}{*}{ Показник } & \multirow{2}{*}{$\begin{array}{c}\text { До ліку- } \\
\text { вання }\end{array}$} & \multicolumn{3}{|c|}{ Після лікування через } & \multirow{2}{*}{$\mathrm{p}_{1}$} & \multirow[b]{2}{*}{$\mathrm{p}_{2}$} & \multirow[b]{2}{*}{$\mathrm{p}_{3}$} & \multirow[b]{2}{*}{$\mathrm{p}_{4}$} & \multirow[b]{2}{*}{$p_{5}$} \\
\hline & & 12 днів & 3 місяці & 6 місяців & & & & & \\
\hline & \multicolumn{9}{|c|}{ перша група } \\
\hline Відчуття печіння & $4,719 \pm 3,718$ & $1,656 \pm 1,945$ & $1,719 \pm 1,887$ & $4,563 \pm 3,519$ & $<0,05$ & $>0,05$ & $<0,05$ & $<0,05$ & $>0,05$ \\
\hline Відчуття холоду & $2,281 \pm 3,353$ & $0,688 \pm 1,299$ & $0,813 \pm 1,256$ & $2,375 \pm 3,415$ & $<0,05$ & $>0,05$ & $<0,05$ & $<0,05$ & $>0,05$ \\
\hline $\begin{array}{l}\text { Відчуття як від } \\
\text { удару струмом }\end{array}$ & $2,281 \pm 3,381$ & $0,531 \pm 1,502$ & $0,594 \pm 0,837$ & $2,031 \pm 2,559$ & $<0,05$ & $>0,05$ & $<0,05$ & $<0,05$ & $>0,05$ \\
\hline $\begin{array}{l}\text { Пощипування, } \\
\text { відчуття повзан- } \\
\text { ня мурашок }\end{array}$ & $3,625 \pm 3,490$ & $2,000 \pm 2,578$ & $2,219 \pm 2,075$ & $3,813 \pm 3,217$ & $<0,05$ & $>0,05$ & $<0,05$ & $<0,05$ & $>0,05$ \\
\hline Поколювання & $2,219 \pm 3,670$ & $1,281 \pm 2,317$ & $1,375 \pm 2,239$ & $2,344 \pm 3,107$ & $<0,05$ & $>0,05$ & $<0,05$ & $<0,05$ & $>0,05$ \\
\hline Оніміння & $3,031 \pm 3,277$ & $1,313 \pm 2,235$ & $1,531 \pm 1,685$ & $3,129 \pm 2,872$ & $<0,05$ & $>0,05$ & $<0,05$ & $<0,05$ & $>0,05$ \\
\hline Свербіж & $1,750 \pm 2,828$ & $0,906 \pm 1,875$ & $1,719 \pm 2,976$ & $1,781 \pm 3,077$ & $<0,05$ & $>0,05$ & $<0,05$ & $<0,05$ & $>0,05$ \\
\hline \multicolumn{10}{|c|}{ друга група } \\
\hline Відчуття печіння & $4,906 \pm 3,771$ & $0,625 \pm 0,942$ & $0,719 \pm 1,529$ & $0,968 \pm 1,231$ & $<0,05$ & $>0,05$ & $<0,05$ & $<0,05$ & $<0,05$ \\
\hline Відчуття холоду & $2,188 \pm 3,487$ & $0,531 \pm 1,344$ & $0,875 \pm 1,827$ & $1,968 \pm 3,238$ & $<0,05$ & $>0,05$ & $<0,05$ & $<0,05$ & $<0,05$ \\
\hline $\begin{array}{l}\text { Відчуття як від } \\
\text { удару струмом }\end{array}$ & $2,406 \pm 3,140$ & $0,406 \pm 1,188$ & $0,438 \pm 1,389$ & $0,531 \pm 1,319$ & $<0,05$ & $>0,05$ & $<0,05$ & $<0,05$ & $<0,05$ \\
\hline $\begin{array}{l}\text { Пощипування, } \\
\text { відчуття повзан- } \\
\text { ня мурашок }\end{array}$ & $4,031 \pm 2,935$ & $1,719 \pm 1,988$ & $1,063 \pm 1,740$ & $1,438 \pm 1,703$ & $<0,05$ & $>0,05$ & $<0,05$ & $>0,05$ & $<0,05$ \\
\hline
\end{tabular}

Примітки:

1) $\mathrm{p}_{1}$ - достовірність показників до лікування і через 12 днів після початку лікування;

2) $\mathrm{p}_{2}$ - достовірність показників на 12 день після лікування і через 3 місяці;

3) $\mathrm{p}_{3}$ - достовірність показників до лікування і через 3 місяці;

4) $\mathrm{p}_{4}$ - достовірність показників на 12 день після лікування і через 6 місяців;

5) $\mathrm{p}_{5}$ - достовірність показників до лікування і через 6 місяців. 
Через 3 місяці у першій групі відчуття печіння, холоду, відчуття як від удару струмом, повзання мурашок, поколювання, оніміння і свербіж турбувало 17 (53,1 \%), 10 (31,3\%), 12 (37,5\%), 20 (62,5\%), 10 (31,3\%), 18 (56,3\%) i 9 (28,1 \%) та в другій групі відповідно 7 (21,9 \%), 7 (21,9 \%), 3 (9,4 \%), $12(37,5 \%), 7$ (21,9\%), 10 (31,3\%) і 5 (15,6\%).

Більшість скарг у хворих, які перебували на стандартній терапії, через 3 місяці відновилися, а у пацієнтів, які додатково пройшли курс лікування келтіканом, позитивний есрект зберігся у 67,4 \% випадків.

Після 6 місячного лікування у пацієнтів першої групи відчуття печіння, холоду, удару струмом, повзання мурашок, поколювання, оніміння і свербіж мали місце у 22 (68,5\%), 12 (37,5\%), 14 (43,8\%), 22 (68,5\%), 15 (46,88\%), 21 (65,6\%) і 9 (28,1\%) та відповідно у 15 (46,88 \%), 10 (31,25\%), 6 (18,8 \%), 16 (50\%), 10 (31,3\%), 13 (40,63\%) і 10 (31,3\%) хворих на діабет другої групи. Позитивний ефрект лікування зберігся у 64,29 \% пацієнтів другої групи.
Порівняння інтенсивності скарг між групами пацієнтів представлено на рисунку.

Таким чином, позитивний клінічний ефект від призначеного лікування як стандартного, так і доповненого келтіканом, спостерігався у всіх хворих з діабетичною полінейропатією, про що свідчило вірогідне поліпшення показників шкали опитувальника DN4 через 12 днів після початку лікування, яке зберігалося і через місяць після терапії. Разом з тим, аналіз відповідей на запитання блоку 13 диференціацією інтенсивності суб'єктивних відчуттів засвідчив збереження клінічного еректу через 3 місяці після проведеної терапії у пацієнтів, яких лікували з додаванням келтікану. Через 6 місяців більшість суб'єктивних відчуттів повернулася до вихідного рівня у пацієнтів першої групи і частини хворих другої групи, що обґрунтовує доцільність повторного курсу запропонованого лікування.
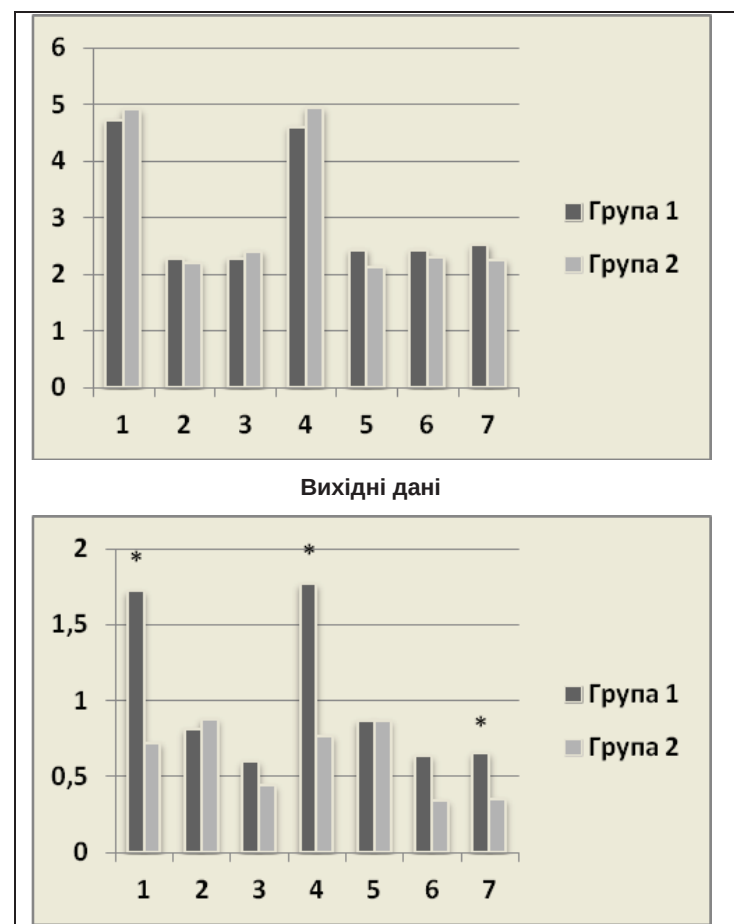

Через 3 місяці

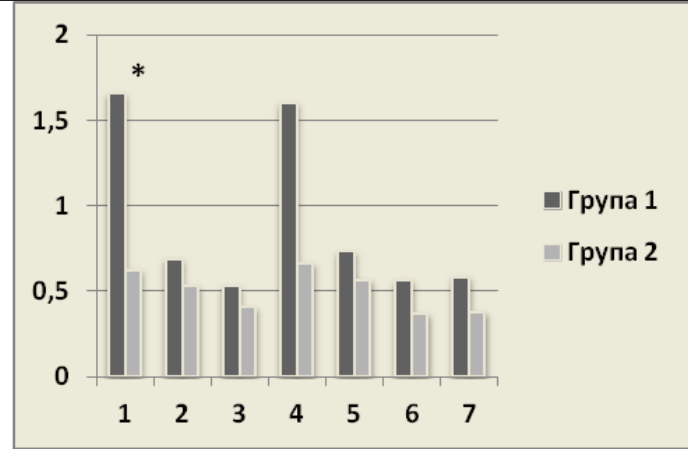

Через 12 днів лікування

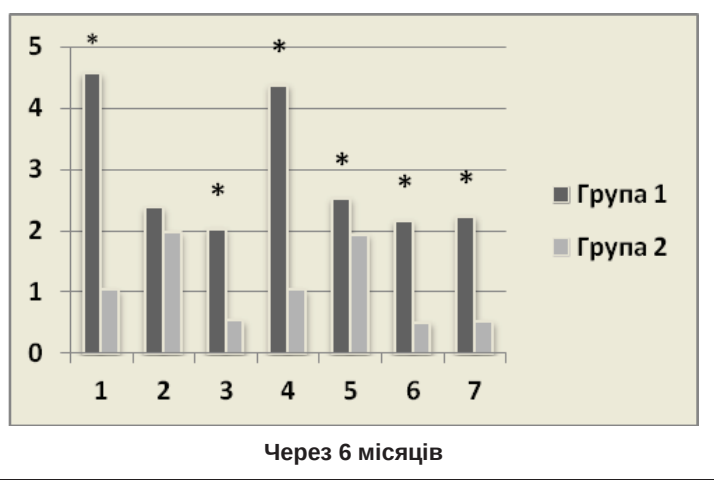

Рис. Динаміка інтенсивності суб'єктивних скарг в обстежених групах хворих під впливом використаних програм лікування. Примітка. * $-p<0,05$

ВИСНОВКИ 1. Використаний опитувальник DN4 3 модифікованою нами шкалою оцінки показників невропатичного болю дозволяє оптимізувати діагностику даного ускладнення у хворих на цукровий діабет.

2. Стандартне лікування діабетичної полінейропатії, відповідно до уніфікованого клінічного протоколу первинної та вторинної (спеціалізованої) медичної допомоги (№ 1118 від 21.12.2012), приводить до тимчасового клінічного ефекту, який зберігався протягом 3 місяців.
3. Включення келтікану в стандартну комплексну терапію діабетичної полінейропатії суттєво підвищує клінічну ефективність лікування невропатичного болю. Лікувальний ефект запропонованої терапії зберігався протягом 6 місяців у 64,2 \% хворих.

Перспективи подальших досліджень Отриманий позитивний клінічний результат лікування келтіканом діабетичної полінейропатії обґрунтовує доцільність вивчення патогенетичних механізмів впливу препарату не лише на невропатичний біль, але і його регенераторні та тросрічні властивості. 
СПИСОК ЛІТЕРАТУРИ

1. Бреговский В. Б. Болевые формы диабетической полинейропатии нижних конечностей: современные представления и возможности лечения : обзор литературы / В. Б. Бреговский // Боль. - 2008. - № 1(18). - С. 29-34.

2. Данилов А. Б. Фармакотерапия болевого синдрома при диабетической полиневропатии / А. Б. Данилов // Consiliummedicum. - 2006. - № 9. - С. 123-126.

3. Данилов А. Б. Нейропатическая боль / А. Б. Данилов, О. С. Давыдов. - М. : Боргес, 2007. - 192-198 с.

4. Котов С. В. Диабетическая нейропатия : 2-е изд., перераб. и доп. / С. В. Котов, А. П. Калинин, И. Г. Рудакова. - М. : ООО “Издательство “Медицинское информационное агентство”, 2011. - С. 440.

5. Кравчун Н. А. Оптимизация медикаментозного лечения диабетической нейропатии: все необходимое доступно / Н. А. Кравчун // Здоровье Украины. - 2007. - № 15. - С. 65.

6. Левин О. С. Лечение болевого синдрома при полинейропатиях. Трудн. пациент / О. С. Левин. - 2007. - № 4. - С. 27-32.

7. Мухина Н. А. Внутренние болезни : учеб. в 2 т. / Н. А. Мухина, В. С. Моисеева, А. И. Мартынова. - М. : ГЭОТАР-Медиа, 2006. - С. 98-145.

8. Про затвердження медико-технологічних документів зі стандартизацією медичної допомоги при цукровому діабеті 2 типу: наказ МО3 України. - Режим доступу://www/moz.qov.ua/ua/ portal/dn_20121221_1118.html

9. Поворознюк В. В. Нейропатичний компонент болю при захворюваннях кістково-м'язової системи : огляд літератури та результати власних досліджень. / В. В. Паворознюк, Т. Є. Шинкаренко, У. І. Приймич : ч. І. Боль. Суставы. Позвоночник. - 2014. - № 4(16). - C. 5-13.

10. Bouhassira D. Comparison of pain syndromes associated with nervous or somatic lesions and development of a new neuropathic pain diagnostic questionnaire (DN4) / D. Bouhassira, N. Attal, H. Alchaar // Pain. - 2005. - Vol. 114. - P. 29-36.

11. Bouhassira D. Development and validation of the Neuropathic Pain Symtom Inventory / D. Bouhassira, N. Attal, J. Fermanian // Pain. - 2004. - Vol. 108

12. Davis M. The prevalence, severity and impact of painful diabetic peripheral neuropathy in type 2 diabetes / M. Davis // Diabetes Care. - 2006. - Vol. 29. - P. 1518-1522.

13. Mibielli M. A. Treatment of acute, non-traumatic pain using a combination of Diclofenaccholestyramine, Uridine Triphosphate, Cytidine Monophosphate, and Hydroxycobalamin / M. A. Mibielli, C. P. Nunes, J. C. Cohen // Proc. West. Pharmacol. Soc. -2010. - Vol. 53. - P. 5-12.

14. Muller D. Лечение невропатических болевых синдромов. Результаты открытого исследования препарата на основе пиримидиновых нуклеотидов / Muller D. // Международный неврологический журнал. - 2011. - № 1(39). - С. 48-50.

Отримано 13.07.17

CM. I. Shved, N. R. Makarchuk, L. P. Martynyuk I. Hobachevsky Ternopil State Medical University

\section{CLINICAL EFFICIENCY OF COMBINED AMINO-ACID COMPLEX USAGE IN COMPLEX TREATMENT OF PATIENTS WITH DIABETIC PERIPHERAL POLYNEYROPATHY}

Summary. Standard treatment of diabetic polyneuropathy, one of the most common diabetes mellitus complications, is effective, but only leads to a temporary clinical effect.

The aim of the study - to increase the efficacy of treatment of neuropathic pain by incorporating Keltican drug into a complex therapy of diabetic polyneuropathy.

Results and Discussion. 64 patients with type 2 diabetes, complicated by diabetic polyneuropathy were examined. Patients were compared into two groups: the control group consisted of 32 patients, who received standard treatment, 32 patients of another group received additionally Keltican (1 capsule three times a day for a month). The assessment and intensity of neuropathic pain was performed using a modified questionnaire DN4. Positive clinical effect of treatment was observed in both groups after 12-day treatment, and was maintained for a month. But such effect was preserved after 3 and 6 months only in the group with Keltican appointment. Conclusions. Using the DN4 questionnaire with a modified scale for evaluating the parameters of neuropathic pain can optimize the diagnosis of this complication in patients with diabetes mellitus. The inclusion of the Keltican in the standard complex therapy of diabetic polyneuropathy increases the clinical efficacy of neuropathic pain treatment and contributes to the preservation of the therapeutic effect for 6 months in $64.2 \%$ of patients.

Key words: diabetic polyneuropathy; neuropathic pain; Keltican.

сн. И. Швед, Н. Р. Макарчук, Л. П. Мартынюк ГВУз “Тернопольский государственный медицинский университет имени И. Я. Горбачевского"

\section{КЛИНИЧЕСКАЯ ЭФФЕКТИВНОСТЬ ИСПОЛЬЗОВАНИЯ КОМБИНИРОВАНОГО АМИНОКИСЛОТНОГО КОМПЛЕКСА В КОМПЛЕКСНОЕ ЛЕЧЕНИИ БОЛЬНЫХ НА ДИАБЕТИЧЕСКУЮ ПЕРИФЕРИЙНУЮ ПОЛИНЕЙРОПАТИЮ}

Резюме. Стандартное лечение диабетической полинейропатии, одного из наиболее частых и распространенных осложнений сахарного диабета, является эффективным, но приводит лишь к временному клиническому эффекту.

Цель исследования - повышение эффективности лечения невропатической боли путем включения препарата "Келтикан" в комплексную терапию диабетической полинейропатии.

Материалы и методы. Наличие невропатической боли диагностировали с помощью модифицированного опросника DN4 (2005). Результаты исследований и их обсуждение. Обследовано 64 больных сахарным диабетом (СД) 2 типа, усложненный диабетической полинейропатией. Пациентов распределили на две группы: в контрольную группу вошли 32 больных, которые получали стандартное лечение, 32 пациента опытной группы дополнительно получали препарат "Келтикан" по 1 капсуле трижды на сутки на протяжении месяца. Оценку интенсивность невропатической боли проводили с помощью модифицированного опросника DN4. Установлен позитивный клинический эфффект лечения в обеих группах после 12-ти дневного лечения, который хранился на протяжении месяца в обеих группах, а через 3 и 6 месяцев лишь в группе с дополнительным назначением келтикана.

Выводы. Использование опросника DN4 с модифицированной шкалой оценки показателей невропатической боли позволяет оптимизировать диагностику данного осложнения у больных сахарным диабетом. Включение препарата "Келтикан" в стандартную комплексную терапию диабетической полинейропатии повышает клиническую эффективность лечения невропатической боли и способствует сохранению лечебного эффректа в течение 6 месяцев в 64,2 \% больных.

Ключевые слова: диабетическая полинейропатия; невропатическая боль; препарат "Келтикан". 